\title{
ERO1A wt Allele
}

National Cancer Institute

\section{Source}

National Cancer Institute. ERO1A wt Allele. NCI Thesaurus. Code C114626.

Human ERO1A wild-type allele is located in the vicinity of 14 q22.1 and is approximately 56

$\mathrm{kb}$ in length. This allele, which encodes ERO1-like protein alpha, is involved in protein folding. 